\title{
Cosmological Aspect in the Contemporary Ukrainian Theological Discourse: the Controversy of the Phenomenological-poetic and Analytical-philosophical School
}

\author{
Svitlana Shkil \\ Doctor of Philosophical Sciences, Associate Professor, \\ National University of Bioresources and Nature Management of Ukraine \\ (Kyiv, Ukraine) \\ E-mail: lauby@meta.ua \\ https://orcid.org/0000-0003-3859-816X \\ Yuriy Chornomorets
}
Doctor of Philosophical Sciences, Professor, National Pedagogical Dragomanov University (Kyiv, Ukraine)
E-mail: palamist@gmail.com
https://orcid.org/0000-0002-1285-9715

\begin{abstract}
There is a confrontation between phenomenological-poetic and analytical-philosophical ways of understanding the relations of "man-universe" in modern Ukrainian theology. The predominance of the first is related to the Orthodox theological culture, which is still a kind of idealism, albeit in postmetaphysical clothing. For Oleksandr Filonenko, the universe is a context for the development of the theoretical anthropological reality. Serhii Sannikov criticizes such a theology, believing that the universe already exists in God's Logos. Understanding the universe as created for God-man's synthesis points to the decisive influence of Russian religious philosophy on the theory of these Ukrainian theologians. However, the influence of the modern Protestant theologian Thomas F. Torrence is important. Ukrainian analytical natural theology of Baptist Fedir Stryzhachuk and Catholic Andrii Baumeyster creatively develops the Plantinga and Swinburne's theory. This theology makes possible to reject critically such idealistic theories, pointing out the possible consequences for the society of theological utopianism. In this respect, Ukrainian theologians re-actualize of Karl Barth's criticism for the natural theology; however, show that analytical natural theology can avoid Barth's arguments. The construction of postmetaphysical natural theology in Ukraine opens up new opportunities for the dialogue between science and religion, philosophy and theology.
\end{abstract}

Keywords: Ukrainian Christian Theology; metaphysical doctrine of analogies; teleology; phenomenology; natural theology

Received: September 12, 2018; accepted: October 16, 2018

(C) Shkil, Svitlana, 2019

(C) Chornomorets, Yuriy, 2019 
Philosophy and Cosmology, Volume 22, 2019: 174-180.

https://doi.org/10.29202/phil-cosm/22/16

\section{Introduction}

Christian theological discourse is divided traditionally into conservative and liberal. The regularity of such a phenomenon from a religious point of view is explained by the fact that liberal theology allows the denomination to acquire new supporters in the dialogue with the world, while the conservative keeps the faithful within the limits of the corresponding tradition. However, the secularization of the outlook already embraced the internal church environment today. Ordinary believers, especially those with a high level of education, need a constant new conversion to their beliefs. In this regard, liberal theology starts to play an even greater role, even in such a generally conservative tradition as Orthodoxy. Within the limits of liberal theological discourse, new attempts to create a comprehensive meta-theory are becoming a new phenomenon. The most interesting project in this respect for today was the monograph of the Kharkiv Orthodox theologian and philosopher Oleksandr Filonenko "The presence of the Other and the gratitude: the contours of the eucharistic anthropology" [Filonenko, 2018]. A characteristic feature of the theological synthesis of Oleksandr Filonenko is the attempt to find the lost unity of humanitarian and natural knowledge, a man and the world, but in the light of theological principles and practices demonstrating the possibility of achieving "holistic knowledge" in the after-postmodernist conditions. Summing up, we can state that the research of Oleksandr Filonenko for the Orthodox theology in the beginning of the $21^{\text {st }}$ century is just as epoch-making, as the work of Father Pavlo Florensky "Pillar and the affirmation of the Truth". However, like the work of Florensky, the presented study is intended to be a certain way, which the reader must go with the author, making sure that the proposed outlook is correct. A similar phenomenon in the Ukrainian Protestant environment was the monograph by Odessa Baptist theologian Serhii Sannikov "The phenomenon of water baptism in the context of modern Baptist sacramentology" [Sannikov, 2018].

In this study, the theological view of the world is presented as a part of general sacramentology - a discipline that studies the forms of the mysterious presence of God in the world. These theological projects are opposed to the analytical natural theology, which is being developed by the Protestant Fedir Stryzhachuk [Stryzhachuk, 2018] and the Catholic Andrii Baumeyster [Baumeyster, 2014].

The purpose of the article is to analyze critically the theological projects of Ukrainian theologians as an attempt to give a new vision of the relationship between man-world and man-God.

\section{Phenomenology of the Beauty of the World in Oleksandr Filonenko's Theology}

The subject of the monograph research by Oleksandr Filonenko is relevant for a number of reasons. First, we note that the Orthodox theology experienced two waves of its own renewal. In the 1920s, the return of Orthodox theologians to their own traditions occurred, resulting in neopatristics as a certain direction of modern theology, aimed at understanding the religious mystical experience gained in the church. In the 1940s, a new wave, the socalled Orthodox Eucharistic theology, which reached its maturity in the 1960s, was gradually 
being formed. The subject of reflection was not what knowledge could be deduced from the religious experience of the believer in the church, but what the church itself is as a Eucharistic community, which influence can bring about the revival of liturgical practices for the renewal of modern man and modern sociality. It can be stated that the neopatristics turned Orthodox to their identity, to their tradition. And the purpose of liturgical theology was to liberate this tradition and the newly arrived identity from the layers of previous epochs. Today, the Eucharistic theology is in a certain crisis of its own legitimization. Namely, the return to tradition or the discovery of more adequate forms for the manifestation of identity ceased to be self-worth. Man is more likely to seek for himself, and the lantern of religion does not help him in these searches.

There is an increasing awareness that the actual purpose of the theological searches was not religious experience and not liberation from the layers of tradition, but God in fact. In this case, a logical question arises: why Orthodox theologians do not seek God today in their personal mystical experience, but in the liturgical experiences of the community. In our opinion, there is a certain influence of the general ideological transformations experienced by globalized humanity in general and philosophical thought in particular. V. Hösle believes that it is possible to distinguish clearly between three types of legitimization of doctrines in the history of philosophy. At the first stage, philosophers turned to objectively existing order. At the second stage - to the structure of subjectivity. At the third stage, the source of legitimizing judgments was an intersubjective community. Moreover, intersubjectivity is a priority subject for research, although, according to V. Hösle, it must be understood in its connection with the subject, with nature and with the Absolute. It can be stated that theologians also move from the modern anthropologically oriented legitimization of their own doctrines, the peak of which was existentialism, to the intersubjective type of argumentation. Accordingly, the term "eucharistic anthropology" from the name of the research by Oleksandr Filonenko has to refer us to a kind of intersubjective anthropology. Indeed, the Ukrainian theologian takes part in a competition for the construction of such anthropology, which would leave behind the dichotomy of individualism and collectivism, but was definitely personalistic and intersubjective. In this, a man can only be a person in an intersubjective community. Moreover, the community is established through constant communication, and not finally given. Thus, the personality's dependence on intersubjectivity can be understood not only holisticly, when the community is a certain One, in the involvement of which there is a plurality of personalities. Intersubjectivity can be a communication that occurs simultaneously with individuals. Moreover, communicating with others and the very existence of another is always a given for me. That is why the term "eucharistic anthropology" from the name of the research by Oleksandr Filonenko can be understood as also relevant to the "anthropology of communication". Indeed, a person as an being intended to interpersonal communication, in which not only with people but also with God, is an object of comprehension in modern Orthodox theology. The spacious place for communication is the beautiful universe, which by its harmony points to the existence of God, the intelligent and personal creative cause of everything. For Oleksandr Filonenko, the beauty of the universe is a phenomenon changing a person's perception of his own vocation, and opens to her the need for a broad view of his own world of wisdom. Namely, not economic activity, and uninterested contemplation should become a way of life in which a person finds himself. In accordance with this, the discovery of the general beauty of the world as a motivating reason for the activity should be to streamline its environment to provide it with beauty and harmony [Filonenko, 2018: 265-310]. 
It should be noted straightaway that the study of Oleksandr Filonenko essentially is the construction of a new Christian humanism. During the dehumanization of both secular and religious space, the Ukrainian theologian deliberately tries to unite Christianity and humanism in modern thought as if there was never a gap between them. It must be stated that dehumanization indeed reached the limit that before returning man to God, he should return to himself, to help find his own humanity. Incidentally, the ides of Oleksandr Filonenko coincides with the ideas of the Ukrainian Protestant theologian Serhii Golovin. We note that the latter is trying to build a two-stage model in the spirit of Thomism or modern speculation. At the first stage, normative morals, apologetics, logic or even quality elements of secular outlook are offered, open to religious ones. At the second stage, however, the need for a pure religious outlook, with the rejection of all previous steps as already unnecessary and questionable, is postulated. Oleksandr Filonenko builds a holistic Christian humanism. He does not recognizes theology without philosophy as well as philosophy without theology. Thus, Oleksandr Filonenko does not reject science or philosophy, ethics or cultural studies after they are used to move towards a purely religious or theological outlook. On the contrary, theology serves as a meta-discourse, which itself is essentially identical with all true philosophy, ethics, culturology, etc. At least, Oleksandr Filonenko thinks as if the inner hidden identity existed in theology with all humanitarian knowledge.

Such a vision is a new Christian Hellenism, in which the whole of modern humanitarian science serves as the achievements of the Greeks. As the Cappadocia believed they had the right to take any of the ancient knowledge and practice in the educational and educational canon, Filonenko also considered it possible and necessary to take certain or other theories of contemporary humanitarianism. Using the latter, he creates a holistic theological pseudo, directing an educated modern man to a new educational re-launch, which results in the formation of not a purely humanitarian, but religious-humanitarian world outlook.

Oleksandr Filonenko tries to overcome the division between not only theology and philosophy, religion and the humanities. He thinks view of the world quite acceptable as a reality, which is intended to be a part of the relationship between God and man. Thus, openness to modern cosmology is postulated. The world is understood as being ready to be the place of God's presence and the place of realization for the unity of God and man [Filonenko, 2018: 211-216].

\section{Metaphysics of phenomenological and hermeneutical understanding of the world harmony in the Ukrainian theology}

All these provisions give us a certain type of Platonic idealism. What is this - idealism, thrown into the very center of human practice, into any conscious activity of man? We must admit that Oleksandr Filonenko describes as a philosopher the ideal theology, ideal philosophy, and perfect humanitarian knowledge, ideal man, perfect meeting with God, ideal God, ideal Church, and ideal universe. Unfortunately, we do not see a full-fledged image of ideal social reality in general, because the author for some reason wants to stay where ethics prevail, staying on the theory of personal ethical responsibility. Indeed, if Oleksandr Filonenko tried to describe the social reality that it should be, it would be obvious utopianism of such an outlook. Instead, all idealized realities are required as a part of the Paideia offered in this theological project to real people for real life. And when the Paideia is completed, there will be already a full person, a free, conscious Christian who will be able to act responsibly in real life, finding a balance between the ideal and the real. Here we would like to recall the opinion of Andrii Baumeyster in his monograph "Being and the Benefit" that 
Heidegger's philosophy, claiming the absence of dualism between existing and communal, actually implies ethical dualism between the existence of a man as it is and the true existence of a man [Baumeyster, 2018: 267-268]. Filonenko's theology emulates the existentialism of the division of man by the available and the kind that man must be to be true. Here you can also remember Sartre, according to which, a person only needs to be by itself, but for this purpose he must be free, act spontaneously.

In general, Oleksandr Filonenko is trying to revive, within the framework of the intersubjective paradigm of thinking, all those elements of Christian humanism that were inherent in religious existentialism. Thus, "eucharistic anthropology" is not actually an anthropology, but is a definite ontology in which God, personality, community, and communication are conceived. All this is interpreted in that dynamic interaction, which is a real life. However, it is meant to show how this life should actually be, if a person lives responsibly and seriously. Accordingly, the vision of the world as a harmonious manifestation is existentially motivated by an ethical vision. This is too little to construct a complete theological theory of human-world relations. The separation between the existing and the ideal-necessary can be overcome only in the eschatological perspective, which has a cosmological aspect. Namely, the entire universe must be absorbed into the Divine Logos as the second Hypostasis of Trinity. This embodiment is in all possible due to the fact that at first God incarnated in man, and through the church reality, the presence of God spread in social reality. The completion of this process must be the existence of God in all things where space would not exist for its own being, but would live the life of God.

These theories of Oleksandr Filonenko are similar to the analogous theories of Oleksii Nesteruk. Presented in the writings of the leading Orthodox theologian, Oleksii Nesteruk, the discourse on modern cosmology and physics is indicative in that its analysis allows us to reveal the significant dependence of Orthodox phenomenology on metaphysics. Thus, with all the attempts to think "after M. Heidegger" and "after J.-L. Marion", the Orthodox theology of Oleksii Nesteruk remains in captivity in the theory of analogies, as well as primitive Platonism and Schlengengism, in the past characteristic of Russian religious philosophy. And being a postmodernist form, Nesteruk's theology remains essentially in the paradigm of liberal theological thinking and religious-philosophical metaphysics of the modern era [Nesteruk, 2014]. Oleksandr Filonenko frees his discourse from metaphysical forms; however, because of this his vision of the universe becomes even less grounded than in Oleksii Nesteruk's theology. Both researchers relate to the attempt to present the old metaphysics of Greek patristics as the result of their own phenomenological and hermeneutic studies of contemporary cosmology by Stephen Hoking, Ilya Prigozhin and other leading scholars and theorists of the philosophy of science.

It should be noted that attention to the concept of "incarnation of God" in the universe as a justification of a certain "spiritual materialism" of Christianity is characteristic not only for modern Ukrainian Orthodox theologians. The relevant motives are found in the reflections of the Baptist theologian and philosopher Mykhailo Cherenkov. However, he has the appropriate theories to justify the openness of Christianity to any social contexts, but do not foresee the construction of a certain natural theology. The emphasis on the "incarnation of God" is intended to legitimize the presence of Christianity in postmodern discourse, to remove suspicion in the spiritualization of the Christian worldview. Thus, metaphysical speculation about the incarnation of God in various kinds of realities must paradoxically prove the possibility of non-metaphysical theology. 
Ukrainian Baptist Theologian Serhii Sannikov creates a more substantiated theory based on his own original methodology [Sannikov, 2018: 77-143]. In this theological system, God is manifested in his work in relation to man and the world, however, while God cannot be defined through definitions. Sannikov believes that God can only be described through the super-categorical definitions, such as Goodness, Beauty, Love, etc. Such definitions may be caused by phenomenological and hermeneutical interpretations of the world as a holistic creation of God. Thus, Sannikov tries to revive those theories that were characteristic of Suarez's metaphysics in post-physical philosophical thinking. In addition, one cannot but notice a certain affinity with the research intentions of Sannikov with the outlook of religious philosophers. With such a methodological approach, the universe becomes a definite gift from God, through the adoption of which man becomes involved with God. Accordingly, Sannikov thinks the total presence of the Word of God in the whole world is not an eschatological perspective, but as an existing reality. This presence is one of the foundations for sacredology. As we can seen, on the contrary, Oleksandr Filonenko, the sacramental spread of the presence of God, is the basis for his presence in the world.

\section{Critique of Metaphysical Approaches and Analytical Theology of Nature in Ukraine}

It should be noted that there is a discussion of modern natural theology in contemporary Ukrainian theology, especially about the theology of Thomas F. Torrance. This theology essentially depends on the cosmology of Greek patristics. Torrance argued that the whole world was intended to translate the Word into it. And this adaptation is manifested in the fact that space and time as the main properties of the universe are such that indicate the world's awareness of man and the adaptability of the world to the future of God-man synthesis. A number of Ukrainian Protestant theologians criticize these theories based on the thoughts of Karl Barth about the impossibility of biblical justification for the natural theology in general and its metaphysical types in particular. Moreover, the Pentecostal researcher Natalia Khromyak points out that the openness to philosophy, natural sciences and the humanities can lead to the construction of such types of natural theology that do not legitimize Christian humanism, and, conversely, become an excuse for the claims of certain conservative ideologies on total power in society [Khromyak, 2018: 37-44]. Karl Barth criticized so sharply all attempts to build Christian natural theology, since all the components of the classical types of natural theology were used by Nazi ideologists to justify this social system as "natural".

The Baptist researcher Fedir Stryzhachuk draws attention to the great potential of analytical natural theology. According to Stryzhachuk, the use of analytical analysis of language and elements of the probability theory in assessing the possibility and adequacy of certain theological pictures of the world, avoids metaphysics in natural theology. Analytical natural theology is a critical discipline similar to Kantian epistemology, and therefore it cannot be the basis for the legitimization of any social theories and ideologies. Indeed, in Stryzhachuk's studies, we see that analytic natural theology does not discriminate on the various types of "holistic knowledge" utopias, the incarnation of God in the universe, does not offer certain models of ecclesiological theories and practices. Analytical natural theology evaluates the harmony of the universe, while avoiding the mysterious and sacramental vision. That is why this natural theology is more in line with the spirit of scientific outlook.

The most widely developed analytical natural theology in the form that was provided to it by A. Plantinga and R. Swinburne, the Ukrainian Catholic theologian Andrii Baumeyster [Baumeyster, 2018: 30-78]. In his view, analytical philosophy is a new scholasticism, which 
is intended to form a certain common language of science, philosophy and theology. Analysis of judgments through the procedures proposed by this new scholasticism allows to select theological judgments on their rational justification even before all attempts to empirically verify them. The possibilities of the latter, Andrii Baumeyster writes, are skeptical, since all attempts at the phenomenal capture of the presence of God in the universe and man seem to him to be frank with mysticism. Accordingly, rational verification of theological theories on coherence and probability is the only possible way of developing natural theology.

\section{Conclusions}

Thus, there is a certain confrontation between phenomenological-poetic and analyticalphilosophical ways of understanding the relations of "man-universe" in modern Ukrainian theology. The predominance of the first is related to the Orthodox theological culture, which is still a kind of idealism, albeit in post-metaphysical clothing. The emergence in Western Orthodox theology of analytic theorists (R. Swinburne) gives hope that the turn to the critical analytical thinking that began in Ukrainian Protestant and Catholic theologies will be supported by Orthodox thinkers. The revealed confrontation between phenomenological and analytical approaches in theology of nature is a natural phenomenon not only for theology, but also for the modern discourse of the religious studies. This confrontation allows seeing the limitations of both methodological programs and the need for new conceptual approaches.

\section{References}

Baumeyster, Andriy. Being and good. Vinnytsya, 2014.

Filipovych, Lyudmyla, and Anatoly Kolodny. Theology and Religious Studies in the Postcommunist Ukraine: History, Modern Status, Perspectives. Numen, 51(1), 2004: 78-93.

Filonenko, Alexander. The Presence of the Other and Gratitude: Contours of the Eucharistic Anthropology. Rivne, 2018.

Khromyak, Nataliya. The Karl Barth's doctrine of natural theology and its reception in modern theological thought. Kyiv, 2018.

Nesteruk, Alexei V. The Universe as a Saturated Phenomenon: The Christian Concept of Creation in View of Modern Philosophical and Scientific Developments. Theology and Science, 12 (3), 2014: 236-259. https://doi.org/10.1080/14746700.2014.927255

Orton, James Douglas and Kari A. O'Grady. Cosmology Episodes: a Reconceptualization. Journal of Management, Spirituality \& Religion, 13(3), 2016: 226-245. https://doi.or $\mathrm{g} / 10.1080 / 14766086.2016 .1159975$

Sannikov, Sergiy. The Phenomenon of Water Baptism in the context of contemporary Baptist Sacramentology. Rivne, 2018.

Stryzhachuk, Fedir. The Bare and Ramified Theism in Theology of Richard Swinburne. Kyiv, 2018 . 